\title{
Experiment Design Effects of Cooling Media Variations Toward Strictness and Pulling Strenghness of Materials of ST 41 in Heat Treatment Process
}

\author{
Sumiati*, Fransisca Diah Ayu Verayanti, Purwati \\ Industrial Engineering Program - Faculty of Engineering - UPN “Veteran” Jatim and Raya Rungkut Madya \\ Gunung Anyar Street, 60294, East Java, Indonesia
}

*Corresponding author:

E-mail:

sumiatiroyana-

wati04982@gmail.com

\begin{abstract}
Steel of ST 41 is the steel be classified as low carbon steel with guide compositions about $0.37-0.43 \% \mathrm{C}, 0.5-0.35 \% \mathrm{Si}, 0.60-0.90 \% \mathrm{Mn}$. The steel sometimes has the unfit characteristic to the need, so It needs another treatment to change characteristic and structure from steel of ST 41 itself be changed in heat treatment methods. Cooling media can affect the strictness characteristics of steel of ST 41 . The heating process in the research uses $723^{\circ} \mathrm{C}$ withholding in an hour. Then it is cooled quickly in many Cooling media. Cooling media be used in the research are water, salt, and coconut oil by using holding time on each Cooling media in 5 to 20 minutes. After done in Quenching process, the steel of ST 41 is done strictness tests and strengths tests to use Rockwell method tests and analyzed. This research result will recommend on general formulation to predict in strictness of steel of ST 41, if it use two co positions namely: $\quad \mathrm{Y}=\quad 97.2118+0.0983^{*} \mathrm{x}-0.4223^{*} \mathrm{y}$ $0.0114^{*} x^{*} x+0.0026 * x^{*} y+0.0023 * y * y$. can predict pulling strength ness of ST 41 material, For a while if they use two compositions namely $\mathrm{Y}=$ $46.7828+0.3293 * x+0.2271 * y-0.0132 * x * x-1.1689 E-14 * x * y-0.0009 * y * y . \quad$ so each $\mathrm{x} 1$ and $\mathrm{x} 2$ areas holding time and temperature.
\end{abstract}

Keywords: Steel of ST 41, Quenching process, Cooling media, strictness tests, strengths tests

\section{Introduction}

The steel of ST 41 is kind medium carbon metals, mean these metals are containing to mixed ferrite and pearlite that they contain the same as big or equal to the steel of S40 C (JIS, G4051), in guide compositions about $0.37-0.43 \% \mathrm{C}, 0.5-0.35 \% \mathrm{Si}, 0.60-0.90 \% \mathrm{Mn}$. The power is exceeded steel of ST 41 has strengths and tenacity well, mean it sometimes is rather an ed its strengths. The steel of ST 41 is chosen for this experiment due the material is easier obtained, other than steel of ST 41 is medium carbon metals, which the steel is classified smooth characteristic but tenacity and strength ness from the steel very well, because the character is needed to be carried out research back to know the formulation of strictness and strength ness on the steel of ST 41.

Therefore one of those efforts to be done to increasing strength ness to do heat and cooling with a step or quickly suitable the need. Changing physical characters on the steel of ST 41 will depend on cooling treatment to be determined. From obstacles, the goal of the research is knowing changing strictness and pulling strength ness on the steel of ST 41 after be done in heat treatment with some of the kind cooling variations such as water, coconut oil, and SAE oil. The method is used namely Rockwell strictness tests. Pulling test, Response Surface Method and Analysis Of Variance to know optimal strictness and be hoped all of four research method that It can find the proper formulation to the strictness and pulling strengthens on the steel of ST 41, so the method is used to as a new tool for the industrial business to determine such as cooling media, holding time, and temperature can raise strictness and pulling strength ness optimally of steel of ST 41 . 


\section{Experiment designs}

Experiment Designs or it often is called with planning experiment is an observation planned to find new facts to strengthen and even to refuse experiment results ever be done before (Arikunto, 2011). New facts will help to determine a recommendation, the example is the recommendation for the dosage of plant fertilization, feed rations well and cheap for dairy cows, medicine dosages properly for disease eradications, and else (Sugiyono, 2010). Planning experiment is a set of rules used to take the sample from research population, to obtained parameter predictions properly and carefully with cost, time along with force limited. With other says, planning experiment is ways to find an answer for the problem in properly and carefully, fit in cost and labor are available (Fatimah, 2017).

\section{Steel}

Steel is mixed metal, Ferro metals have functioned as bottom elements are mixed with some of the other elements, included carbon element, carbon steel is one of the kinds mixed steel to consist on Ferro element (Fe) and Carbon (C) (Bachtiar, 2012). Ferro is the bottom element and carbon as mainly mixed elements. In the process makes steel that it can be found the addition of contents on other chemical elements such as sulfur (S), phosphor (P), silicon (Si), Manganese (Mn), and other chemical elements to suitable with steel characteristics wanted. Carbon steel has a content of carbon bottom into Ferro about $0.2 \%$ to $2.14 \%$, where the carbon contents have functioned as amplifier elements in the steel structure (Taryana \& Nofri, 2017). The steel of ST 41 is kind of low carbon metals, it means that this metal consists of mixed ferrite and pearlite in the contents alike large or equal with the steel of S 40 C (JIS, G4051), with mixed compositions $0.37-0.43 \% \mathrm{C}, 0.5-0.35 \% \mathrm{Si}, 0.60-0.90 \% \mathrm{Mn}$. Adding power to the steel of ST 41 has strengths and tenacity good enough, that's mean that it sometimes needs to be raised strengths (Ardiansah, 2019).

\section{Holding time}

Holding time is done to get maximum strictness from a material in the hardening process with retaining in amplifier temperature to obtain heating in homogenous so that austenite structure of homogenous or happened carbide solubility into austenite and carbon diffusion and the composite elements (Sunaryo, 2013). Guidelines to determine holding time from various kind steel:

1. Construction steel from carbon steel and low composite steels content carbide are soluble easily, needed holding time briefly about 5 to 20 minutes after reach heating temperature considered adequate.

2. Construction steel from medium composite steels suggested to use holding time range 15 to 25 minutes, not depended on workpiece size.

3. Low Alloy Tool Steel needs holding time properly, to strictness to wanted getting reached. To suggested uses 0.5 minutes per millimeter on a thick object or 10 to 30 minutes (Surdia \& Chiijiwa, 2010).

4. High Alloy Chrome Steel needs holding time is the longest among all of the steel alloys, depending on heating temperature. It is a needed temperature combination and holding time properly. Those are as usual suggested to use 0.5 minutes perimeter of a thick object with a minimum of 10 minutes, maximum an hour.

5. Hot work tool steel contains carbide of difficult solubility, just solubility at $1000^{\circ} \mathrm{C}$. At this temperature maybe happen to the growth of the granule very large. Because this holding time must be restricted, 15 to 30 minutes. High-Speed Steel need heating temperature the highest, $1200-1300^{\circ} \mathrm{C}$. To prevent happens growth of granule in holding time taken a lot of time only. An example we take in holding time is for 15 minutes on 8200 temperature (Rianto, 2014). 


\section{Cooling media}

Cooling media on the heat treatment process is necessary for forming metal structures. Cooling is moving heat from a place by other places be followed by changes in the place wanted (from heat to cool) (Januar, 2016).

1. Media of Cooling water ( $\mathrm{V}=998 \mathrm{~kg} / \mathrm{m} 3$ )

Water is a chemical compound with the chemical formulation of H20. Mean one water molecule to be arranged on two hydrogen atom bound on one oxygen atom. Water has uncolor characteristics, no felt, no smelt. Water has a freezing point $0^{\circ} \mathrm{C}$ and a boiling point, water density is lower saltwater so the cooling rate slower than saltwater. The matter is caused by the distance between atoms in water more closely and produces martensite structure of granule is bigger.

2. Cooling media of Salt Water $(\mathrm{V}=1025 \mathrm{~kg} / \mathrm{m} 3)$

Saltwater is used as cooling element caused has characteristics to cool regular and rapid. The element is cooled into salt liquids that it will due to the ties harder cause on the workpiece surface will the ties carbon. the cooling rate is faster than other cooling media. Cristal granules are capable of absorve martesit produce characteristics hard and brittle.

3. Cooling media of oil ( $\mathrm{V}=981 \mathrm{~kg} / \mathrm{m} 3$ )

Oil is used as cooling fluid in heat treatment is obtain to give workpiece layer procced. Besides, especially oil is used to burn oil or oil. Oil viscosity and base oil elements are affected in the sample cooling process. The oil has viscosity is lower, cooling slower compared the both. Producing ferit structure and pearlit even faster than diesel fuel. Oil has a boiling point of $100^{\circ} \mathrm{C}$.

4. Cooling media of Air

Cooling Air is done to heat treatment to need cooling slowly. To the need that air is circulated in the cooling room to make speed low. The air is as cooling to give opportunities for metals of forming crystals and maybe binding other elements from the air (Prasetyo, 2019).

\section{Response surface method}

The response surface method is a method that often is used in experiment design, method base idea is utilized to experiment design with helping statistics to find optimal value from a response (Irianto, 2010). The researcher can know variables values of independent cause response variable value to be optimally arranged a mathematics model. The General problem method on the response surface is to the correlation between the response variable with the independent variable unknown. Therefore, step first in the response surface method is looking for connection form between response with some of the independent variable through connection form tried first time due is connection form simply (low order polynomial). Linear connection form is if the turn of connection form between response independent variable is a linear function, the approach of function is called the first-order model, such as showed in the equation as follows.

$$
\mathrm{Z}={ }_{\beta} 0+{ }_{\beta} 1 \mathrm{y} 1+{ }_{\beta} 2 \mathrm{y} 2+\ldots \ldots \ldots+{ }_{\beta} \mathrm{lyl}+\varepsilon \mathrm{j} .
$$

If connection form is square, so to approach of the function is used polynomial degree higher namely second-order (Iriawan, 2012)

$$
\mathrm{Y}={ }_{\beta} 0+\sum_{i=1}^{k} \quad{ }_{\beta} \mathrm{ixi}+\sum_{i=1}^{k} \quad{ }_{\beta} \mathrm{iix} \mathrm{i}^{2}+\ldots \ldots+{ }^{\sum_{i<j}} \quad \sum_{\beta} i j x i x j+\varepsilon
$$

Almost all of the problems in the response surface method is one of them or both models after obtained to connection form more suitable, the next step is optimizing the correlation. If the surface is more suitable be sought through enough approach, so analysis result will close truly function (Yamin \& Kurniawan, 2014). 


\section{Analysis of variance}

Analysis Of Variance is a statistical method to analyze one effect or more independent variables of category scale, which is named "factor" to the dependent variable namely the response is continuously scaled. At beginning of progress, variance analysis be designed to analysis for the data of the experimental study, however in the next progress, because various theoretical obstacles or substantive to do carrying out the experimental study, variance analysis be used to analyze the data to observe the study, although in theoretical for validity value that the result is lower than analysis result of the data of experimental study (Sugiyono, 2016).

\section{Research Method}

In doing research, need is done to steps of solving the problem. Following steps of solving the problem in the research. Step one is collecting data which have four items, as follows:

1. Strictness value of the material of ST 41 on some of the variations on cooling media

2. Pulling strengthness values of the material of ST 41 on some of the variations on cooling media

3. Level data and factors affecting the experiment

4. Data of P-Value

For processing data of experiments uses Surface Response and variance analysis method

\section{Results and Discussion}

\section{Collecting data}

Before doing the data process, so early steps need to be done is to collect data be related to the research object namely the material of ST 41.

\section{Data for holding time}

As for data of holding time to be used in this research is involving as follows:

Table 1. Data for holding time

\begin{tabular}{lc}
\hline Holding time & Cooling Media \\
\hline & Water \\
Saltwater & Coconut oil \\
& oil \\
& water \\
10 minutes & Saltwater \\
& Coconut oil \\
& oil \\
& water \\
& Saltwater \\
& Coconut oil \\
& oil \\
& water \\
& Saltwater \\
& \\
& \\
& Coconut oil \\
\end{tabular}


Strictness data of material of ST 41 after test result (HCR)

Based on table 1 known early standard of material strictness of ST 41 then obtained strictness result from the material of ST 41 had tested by Rockwell machine namely as follows:

Table 2. Machine Of Rockwell Machine Test

\begin{tabular}{ccc}
\hline Cooling Media & Holding time (minutes) & Strictness Steel of ST 41 (HRC) \\
\hline \multirow{3}{*}{ Water } & 5 & 79 \\
& 10 & 79.5 \\
& 15 & 82 \\
Salt water & 20 & 82.5 \\
\hline \multirow{5}{*}{ Oil coconut } & 5 & 69 \\
& 10 & 69.5 \\
& 15 & 70 \\
& 20 & 73 \\
\hline & 5 & 59 \\
& 10 & 62 \\
& 15 & 62.5 \\
& 20 & 63 \\
\hline & 5 & 52 \\
& 10 & 52.5 \\
& 15 & 53.5 \\
& 20 & 55 \\
\hline
\end{tabular}

Strengthness data of pulling material of ST 41 after test result ( $k N$ )

Based on research had been done, obtained pulling strength ness result from the material of ST 41 had tested by pulling test machine namely as follows:

Table 3. Strengthness data of pulling material of ST 41 after test result (KN)

\begin{tabular}{ccc}
\hline \multirow{2}{*}{ Cooling Media } & Polding time & Pulling Steel Strengthness of T 41 \\
& $(\mathrm{kN})$ \\
\hline \multirow{3}{*}{ Water } & 5 & 60 \\
& 10 & 61 \\
& 15 & 62 \\
& 20 & 64 \\
\hline \multirow{3}{*}{ Salt Water } & 5 & 59 \\
& 10 & 59.5 \\
& 15 & 60 \\
& 20 & 63 \\
\hline & 5 & 59.4 \\
Coconut Oil & 10 & 59.5 \\
& 15 & 60 \\
& 20 & 61 \\
\hline
\end{tabular}




$\begin{array}{ccc} & 5 & 52 \\ \text { Oil } & 10 & 52.5 \\ & & \\ & 15 & 53.5 \\ 20 & 60\end{array}$

\section{Processing data}

Based on Table 1, so further be done processing data to determine optimal strictness on the material of ST 41 with cooling media which is different, and holding time will be analyzed to use analysis of Variance.

\section{Heat treatment process}

This process is used for the modification of steel microstructure so getting changes steel mechanic characteristics.

\section{Normalizing process}

This process is initiated by heating the test object at temperature $723^{\circ} \mathrm{C}$ for a hour all part of the test specimens the same temperatures.

\section{Quenching process}

A hardening steel process, with steel ways, is heated to reach the austenite limit and then followed with cooling fast process through cooling water media, saltwater, coconut oil, and oil.

Analysis of strictness experiment results with response surface method

Analysis result of order I show that value P bigger about 0,509 from significant level be determined about 0.05 . So, getting a equation to search water strictness value on material of ST 41 as follows : $Y=97.2118+0.0983^{*} \mathrm{x}-0.4223^{*} \mathrm{y} 0.0114^{*} \mathrm{x}^{*} \mathrm{x}+0.0026^{*} \mathrm{x}^{*} \mathrm{y}+0.0023{ }^{*} \mathrm{y}^{*} \mathrm{y}$.

Analysis of response surface characteristics

Analysis result with Minitab 16 software produces two figures are chart contour and surface.
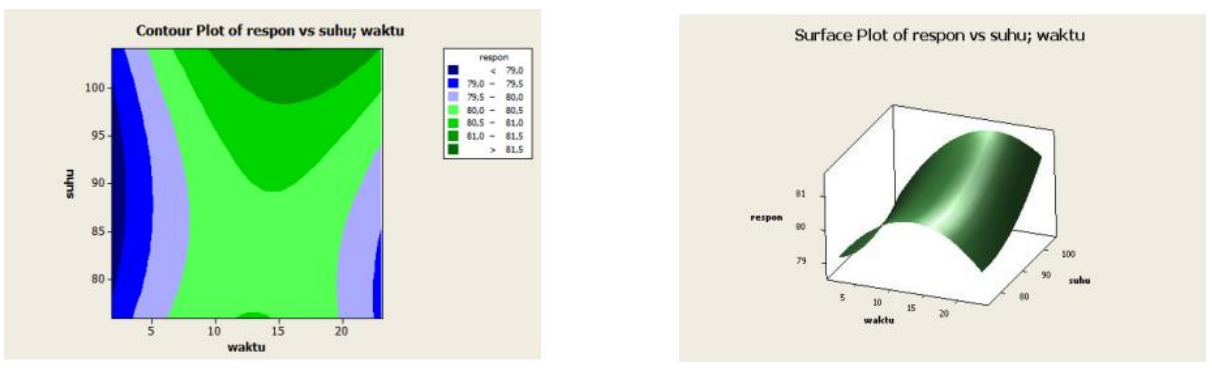

Figure 1. Contour Plot and strictness plot Surface

\section{Optimization Plot}

Determining combination levels is based on analysis with the quadric model so it could be obtained proportion each variable X1 and X2 that it will produce response y most optimal. Which in time variable (X1) about 16 minutes and the temperature variable (X2) about $104.1421^{\circ} \mathrm{C}$. Both variables are effected significant could plot optimum form linear curva namely $81.5 \mathrm{HRC}$ and raise material strictness of ST 41. 


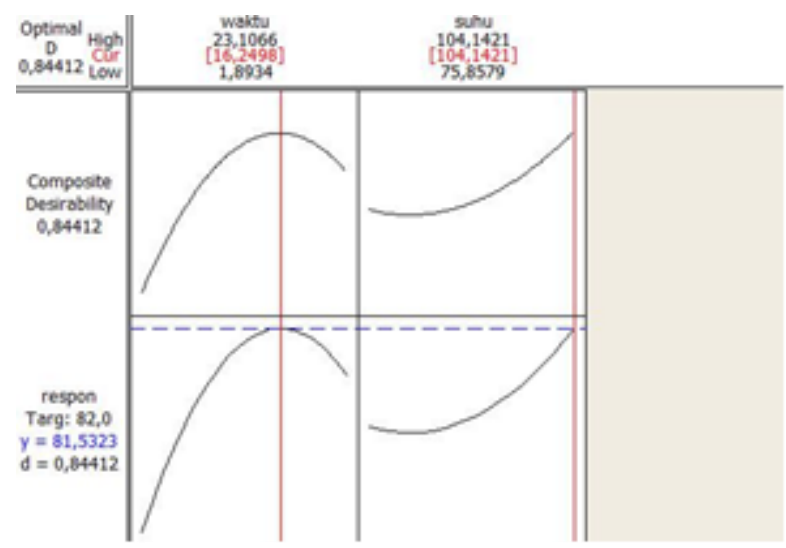

Figure 2. Plot optimum result

Analysis of pulling experiment result with response surface method

Analysis result of Order 1 shows value - P bigger namely 0.866 from significant level which it is determined about 0.05 , so producing an equation to search water strictness value on the material of ST 41.

Analysis of response surface characteristics

The condition is the maximal est for plot above old green color with pulling test value up 63 HRC.

\section{Optimization plot}

Optimization plot results in which it is time variable (X1) about 12 minutes and temperature variable (X2) about $104.1421^{\circ} \mathrm{C}$, forming a linear curve up toward optimum condition with optimal strictness namely $63 \mathrm{kN}$. The mean is adding this variable will raise the material strictness of ST 41.

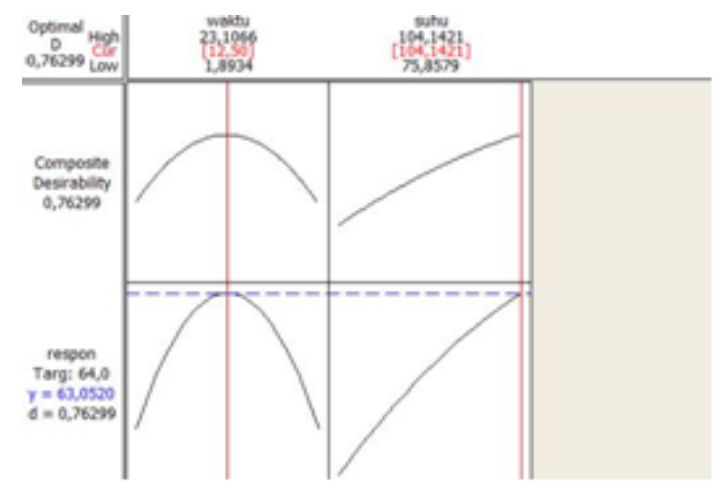

Figure 3. Plot optimal result

From the research of material strictness tests of ST 41 is obtained strictness value on cooling water media with holding time 5, 10, 15, and 20 minutes about 79, 79.5, 8, and 82.5 on cooling media of saltwater $69,69.5,70$, and 73 on cooling media of coconut oil 59, 62, 62.5, and 63 and cooling media of oil 52, 52.5, 53.5, and 55. From the research of material strictness tests of ST 41 is obtained strictness value on cooling water media with holding time $5,10,15$, and 20 minutes about $79,79.5,8$, and 82.5 on cooling media of saltwater $69,69.5,70$, and 73 on cooling media of 
coconut oil 59, 62, 62.5, and 63 on cooling media of oil 52, 52.5, 53.5, and 55. From research strength, ness tests of pulling material of ST 41 is obtained pulling strengthness values on cooling water media with holding time 5, 10, 15, and 20 minutes about $60,61,62$ and 64 on cooling media of saltwater 59,59.5, 60, and 65 on cooling media of coconut oil 59.4, 59.5, 60, and 61 on cooling media of oil 52, 52.5, 53.5, and 60 .

From research is obtained material proportion result which it can produce strictness most optimal for the material of ST 41 is with holding time 21 minutes with $104^{\circ} \mathrm{C}$ temperature so that produce strictness is $82 \mathrm{HRC}$. So to produce a general equation to predict material strictness of ST 41 if it uses mixed material. While material proportion result can produce pulling strengthness most optimal for the material of ST 41 is holding time 12 minutes with $104^{\circ} \mathrm{C}$ temperature that can produce optimal strictness namely $63 \mathrm{kN}$. To produce a general equation to predict material strictness of ST 41 if it uses mixed material.

\section{Conclusion}

From the research of strength ness tests of pulling material of ST 41 is obtained pulling strengths values on cooling water media with holding time $5,10,15$, and 20 minutes about 60,61 , 62 , and 64 on cooling media of saltwater $59,59.5,60$, and 65 on cooling media of coconut oil 59.4, $59.5,60$, and 61 and on cooling oil media $52,52.5,53.5$, and 60 . So that can conclude that water is with holding time 21 minutes with heating water temperatures $104^{\circ} \mathrm{C}$, has strictness value most optimal, because more and more holding time so it will be affected to strictness and strengths of pulling material of ST 41. Another research value can be concluded that water is in holding time 12 minutes with a heating water temperature of $104^{\circ} \mathrm{C}$, has to pull strengths values most optimal because it is more and more holding time, so it will be affected for material strictness of ST 41.

\section{Acknowledgment}

This work was financially supported by Industrial Engineering Program - Faculty of Engineering - UPN "Veteran" Jatim. Therefore, we are grateful for this funding and support of this research.

\section{References}

Ardiansah, A. (2019). Studi hasil proses pengelasan fcaw (flux cored arc welding) pada material st 41 dengan variasi media pendingin terhadap kekuatan tarik dan struktur mikro. Jurnal Teknik Mesin, 7(2), 9-16.

Arikunto, S. (2011). Prosedur penelitian suatu pendekatan praktik, Ed Revisi VI. Jakarta: PT Rineka Cipta.

Bachtiar. (2012). Modul ajar praktek las. surabaya: Politeknik Perkapalan Negeri Surabaya.

Fatimah, N. (2017). Analisa pengaruh variasi media pendingin terhadap kekuatan mekanik pada hasil pengelasan metode SMAW baja ST 52. Balikpapan: Politeknik Negeri Balikpapan.

Irianto, A. (2010). Statistik konsep dasar \& aplikasinya. Jakarta: Kencana

Iriawan, N. (2012). Mengolah data statistik dengan mudah menggunakan minitab 16. Yogyakarta: Andi.

Januar, A. (2016). Kajian hasil proses pengelasan MIG dan SMAW pada material st 41 dengan variasi media pendingin (air, collent, dan es) terhadap kekuatan tarik. Surabaya: Teknik Mesin Universitas Negeri Surabaya.

Prasetyo, D. (2019). Variasi media pendingin pada proses heat treatment baja karbon st41 untuk pisau potong plat beton. Doctoral Dissertation, Universitas Pancasakti Tegal.

Rianto, E. (2014). Pengaruh temperatur quenching terhadap kekerasan dan ketangguhan hasil pengelasan baja keylos 50. Surakarta: Teknik Mesin Universitas Sebelas Maret.

Sugiyono. (2010). Metode penelitian kuantitatif kualitatif \& RND. Bandung: Alfabeta.

Sugiyono. (2016). Statistika untuk penelitian. Bandung: Alfabeta

Sunaryo, H. (2013). Teknik pengelasan kapal jilid 1 dan 2. Jakarta: Direktorat Pembinaan Sekolah Menengah Kejuruan

Surdia, T., \& Chiijiwa, K. (2010). Pengetahuan bahan teknik. Jakarta: PT Pradnya Paramita.

Taryana, A., \& Nofri, M. (2017). Analisis sifat mekanik baja SKD 61 dengan baja ST 41 dilakukan hardening dengan variasi temperatur. Jakarta: Teknik Mesin Institut Sains dan Teknologi Nasional.

Yamin, S., \& Kurniawan, H. (2014). Teknik analisis statistik terlengkap dengan software SPSS. Jakarta: Salemba Infotek. 